\title{
RANCANG BANGUN SISTEM INFORMASI REGISTRASI TEMPAT USAHAUNTUK MENDUKUNG PEMETAAN WILAYAH
}

\author{
Yusuf Effendy ${ }^{1}$ \\ Ruli Supriati ${ }^{2}$ \\ Silva Ayu Lestari ${ }^{3}$ \\ Dosen STMIK Raharja ${ }^{1,2}$, STMIK Raharja Jurusan Sistem Informasi ${ }^{3}$ \\ Jl. Jendral Sudirman no.40, Modern, Cikokol Tangerang ${ }^{12,3}$ \\ Email : yusuf.effendy@raharja.infor ${ }^{1}$,ruli@raharja.info ${ }^{2}$,silva.ayu@raharja.info ${ }^{3}$
}

\begin{abstract}
ABSTRAK
Dalam penelitian ini mengambil lokasi riset dengan studi kasus di Kantor Kecamatan Kosambi Kabupaten Tangerang. Proses registrasi tempat usaha yang ada saat ini masih tertinggal, karena diera globalisasi sekarang pembuatan surat izin tempat usaha masih menggunakan manual, dimana penduduk menunggu sampai beberapa hari untuk mendapatkan surat izin tempat usaha. Metodologi yang digunakan dalam penelitian ini yaitu metode pengumpulan data berupa observasi, wawancara, study pustaka, metode analisa menggunakan analisis PIECES. Pada penelitian ini disajikan pembahasan tentang landasan dan tahapan dalam menganalisa dan modelling sistem registarsi tempat usaha dengan menggunakan unified modelling language (UML) yang digambarkan dengan usecase diagram, activity diagram, sequence diagram, dan class diagram. Tujuan dalam penelitian ini, untuk melakukan proses perencanaan sistem registarsi tempat usaha, peneliti memberikan masukan untuk membuat sistem informasi registrasi tempat usaha. Dengan sistem informasi registrasi tempat usaha ini, diharapkan sumber daya yang ada dapat digunakan secara optimal.
\end{abstract}

Kata kunci : Surat Registrasi Tempat Usaha, SITU, SKDU.

\section{ABSTRACT}

In this study took the location of research with case studies at the District Office Kosambi Tangerang District. The current business registration process is still lagging behind, as globalization now makes the place permit still using the manual, where the population waits for several days to get the business place permit. The methodology used in this research is the method of collecting data in the form of observation, interview, literature study, analysis method using PIECES analysis. In this study, there is a discussion about the foundation and stages in analyzing and modeling registarsi system of business place by using unified modeling language (UML) which is described with usecase diagram, activity diagram, sequence diagram, and class diagram. The purpose of this study, to perform the process of registarsi system of place of business planning, the researcher gives input to make information system of registration of place of business. With this business registration information system, it is expected that the existing resources can be used optimally.

Keywords: Letter of Business Registration, SITU, SKDU.

\section{PENDAHULUAN}

Di era globalisasi saat ini perkembangan teknologi dan informasi sudah berkembang dengan sangat pesat dalam segala bidang. Teknologi pada saat ini sudah 
semakin berkembang di Indonesia. Salah satunya teknologi informasi yang semakin berkembang dan mengambil peranan penting pada instansi pemerintah. Setiap organisasi seperti halnya Instansi Pemerintah juga sangat membutuhkan sistem komputerisasi yang akurat, cepat dan tepat. Hal tersebut membuktikan bahwa kini teknologi menjadi salah satu penunjang aktivitas manusia.

Semua sistem informasi memiliki karakteristik umum yang sama, yaitu selalu tumbuh dan berkembang dalam melaksanakan tugas-tugas yang berhubungan dengan pengelolaan data dan menyediakan informasi kepada user. Dalam pembuatan suatu sistem informasi, komputer sangat membantu untuk memproses data yang kuantitasnya besar dan keakuratan komputer dapat diandalkan. Oleh karena itu komputer memberikan pengaruh yang cukup besar dalam penghematan dan efisiensi waktu serta membantu untuk mencapai suatu sistem informasi yang tepat, cepat dan akurat.

Namun pada saat ini, masih terdapat instansi pemerintah yang masih menggunakan sistem manual dalam penyelesaian suatu pekerjaan. Jika dibandingkan dengan pengolahan data secara manual, pengolahan data secara terkomputerisasi memiliki kelebihan, seperti: pengolahan data yang lebih cepat dan akurat, serta mendukung pengolahan data dalam skala besar.

Salah satunya pada Kantor Kecamatan Kabupaten Tangerang yang hingga saat ini dalam proses pembuatan surat izin tempat usaha masih berjalan secara manual, sehingga mengakibatkan proses tersebut tidak berjalan secara efektif. Seiring perkembangan teknologi dan informasi, dengan adanya sistem informasi registrasi tempat usaha yang terkomputerisasi akan dapat memudahkan pegawai dalam membuat surat izin tempat usaha, sehingga dapat lebih efektif dan efisien.

\section{LANDASAN TEORI}

\section{Pengertian Perancangan}

Menurut Deni Darmawan dan Kunkun Nur Fauzi (2013:228) Perancangan sistem adalah sebuah proses yang menentukan bagaimana suatu sistem akan menyelesaikan apa yang mesti diselesaikan.

\section{Pengertian Registrasi}

Menurtut Yasir Riadi, dkk (2014:10) Registrasi adalah suatu kegiatan pencatatan yang dilakukan pertama kali pada saat melakukan pendaftaran maupun ketika akan melanjutkan.

\section{METODE PENELITIAN}

Dalam melaksanakan penelitian ini digunakan beberapa metodologi penelitian, yaitu sebagai berikut :

\section{a. Metode Pengumpulan Data}

Metode Observasi (Observation Research), adalah kegiatan yang dilakukan peneliti untuk mengumpulkan data dan mendapatkan hal-hal yang diperlukan untuk proses penelitian dengan cara mendatangi objek penelitian secara langsung pada instansi pemerintah tersebut. 
Metode Wawancara (Interview Research), adalah proses memperoleh keterangan untuk tujuan penelitian dalam proses mengambil data dengan cara tanya jawab sambil bertatap muka antara pewawancara dan narasumber pada instansi pemerintah tersebut.

Metode Studi Pustaka (LiteraturReview), adalah teknik pengumpulan data dengan melakukan penelaahan terhadap berbagai buku, literatur, catatan, serta berbagai laporan yang berkaitan dengan masalah yang ingin dipecahkan.

\section{b. Metode Analisa}

Metode analisa pada penelitian ini menggunakan metode analisa PIECES (Performance, Information, Economic, Control, Efficiency, Service). Analisa PIECES berfungsi sebagai salah satu metode analisa sebuah sistem untuk mengidentifikasikan sebuah masalah. Dalam menganalisis sebuah sistem, terdiri dari beberapa aspek antara lain :

- Analisis Kinerja (Performance) adalah suatu kemampuan sistem dalam menyelesaikan tugas dengan cepat sehingga sasaran dapat segera tercapai.

- Analisis Informasi (Information) merupakan hal yang penting karena dengan informasi tersebut pihak manajemen dan user dapat melakukan langkah selanjutnya. Apabila kemampuan sistem informasi lebih baik, maka user akan mendapatkan informasi yang akurat dan relevan sesuai dengan yang diharapkan.

- Analisis Ekonomi (Economy) adalah Pemanfaatan biaya yang digunakan dari pemanfaatan informasi. Peningkatan terhadap kebutuhan ekonomis mempengaruhi pengendalian biaya dan pebingkatan manfaat.

- Analisis Keamanan(Control) yaitu analisis yang digunakan untuk membandingkan sistem yang dianalisa berdasarkan pada segi ketepatan waktu, kemudahan akses, dan ketelitian data yang diproses.

- Analisis Efesiensi (Efeciency) yaitu berhubungan dengan bagaimana sumber tersebut dapat digunakan secara optimal. Operasi pada suatu instansi dikatakan efisien atau tidak biasanya didasarkan pada tugas dan tanggung jawab dalam melaksanakan kegiatan.

- Analisis Layanan (Service) adalah peningkatan pelayanan memperlihatkan kategori yang beragam. Proyek yang dipilih merupakan peningkatan pelayanan yang lebih baik, user dan bagian lain yang merupakan simbol kualitas dari suatu sistem.

\section{c. Metode Perancangan}

Metode perancangan sistem yang digunakan untuk membangun sistem informasi registrasi tempat usaha yaitu dengan alat bantu menggunakan Unified Modelling Language (UML) yang berupa use case diagram, activity diagram, sequence diagram, class diagram.

\section{PERMASALAHAN}

Setelah melakukan analisa proses registrasi tempat usaha yang ada pada Kantor Kecamatan Kabupaten Tangerang. Permasalahan yang sedang dihadapi terbilang cukup tertinggal dikarenakan diera globalisasi sekarang proses pembuatan surat perizinan tempat usaha masih menggunakan manual yaitu penduduk diharuskan datang ke kantor 
kecamatan dan menunggu sampai beberapa hari untuk mendapatkan surat izin tempat usaha tesebut. Pegawai di kecamatan diharuskan menginput dan memproses surat permohonan secara manual sehingga membutuhkan waktu yang lama untuk menerbitkan surat izin tempat usaha tersebut.

\section{LITERATUR REVIEW}

Dengan adanya studi pustaka (literatur review) ini untuk mengidentifikasi kesenjangan, meneruskan penelitian yang sudah dilakukan sebelumnya dan menghindari pembuatan ulang.

1. Penelitian ini dilakukan oleh Bahram, Taufiq, dan Rustati Rahmi pada tahun 2015denganjudul "Aplikasi Permohonan Surat Izin Tempat Usaha Berbasis Web Di Kantor Kelurahan". Penelitian ini bertujuan untuk merancang aplikasi permohonan surat izin tempat usaha pada kantor kelurahan berbasis web.

2. Penelitian ini dilakukan oleh Nazarius Hendro Ando pada tahun 2013yang berjudul "Implementasi Kebijakan Pengurusan Surat Izin Tempat Usaha Di Kecamatan Nanga Taman Kabupaten Sekadau". Penelitian ini bertujuan untuk mendeskripsikan proses pelaksanaan Izin Usaha Pemeliharaan yang telah diberikan oleh Bupati Sekadau sesuai dengan Surat Keputusan No. 4 tahun 2006 tentang pengelolaan izin lokasi usaha.

3. Penelitian yang dilakukan olehSandi Yusmantoro, dkk pada tahun 2014yang berjudul "Rancangan Bangun Aplikasi Pengamanan Keaslian Surat Izin Tempat Usaha Menggunakan Algoritma ElGamal dan Secure Hash Algorithm 256 Studi Kasus: Badan Pelayanan Perizinan Terpadu (BPPT) Kota Bengkulu”. Penelitian ini bertujuan untuk menghasilkan suatu aplikasi pengamanan keaslian SITU yang dapat digunakan mengamankan keaslian SITU dan melakukan autentikasi SITU.

4. Penelitian yang dilakukan oleh Pacoyama Oktara Akbar pada tahun 2013dengan judul "Analisis dan Perancangan Sistem Informasi Registrasi Online Berbasis Web". Dalam penelitian ini penulis menggunakan bahasa pemograman Java dan database MySQL serta merancang web menggunakan metode UML (Unified Modelling Language). Tujuan dari pembuatan sistem ini adalah mempermudah calon peserta audisi dalam melakukan registrasi dan mendapatkan jadwal audisi.

5. Penelitian yang dilakukan oleh Damba Putra pada tahun 2017 yang berjudul "Kebijakan Pemerintah Dalam Memberikan Izin Usaha Industri Kecil di Kota Bandar Lampung”. Berdasarkan Permendagri No 24 Tahun 2016 tentang Pedoman Penyelenggaran Pelayanan Terpadu Satu Pintu yang ditandaklanjuti dengan Peraturan Walikota Kota Bandar Lampung No. 58 Tahun 2011 tentang Tugas, Fungsi, dan Tata Kerja Penanaman Modal Dan Perizinan Kota Bandar Lampung bahwa pemberian izin UMKM di kota Bandar Lampung dilakukan oleh lembaga Badan Penanaman Modal dan Perizinan Terpadu Satu Pintu sesuai dengan peraturan yang berlaku. 


\section{PEMBAHASAN}

Dalam pengolahan data registrasi tempat usaha pada Kantor Kecamatan yang dilakukan oleh bagian Pelayanan Terpadu (PATEN) masih terdapat kekurangan diantaranya :

a. Proses pendataan permohonan berkas surat izin tempat usaha masih menggunakan buku agenda yang bisa saja rusak atau hilang, serta proses pembuatan laporan yang belum tertata dengan baik.

b. Penyimpanan arsip surat masih menggunakan rak-rak atau lemari, sehingga arsip surat tersebut menjadi tertumpuk dan tersebar.

c. Kekurangan sistem komputerisasi yang terdapat pada Kantor Kecamatan Kosambi itu sendiri, meliputi sumber daya perangakat keras dan terbatasnya perangkat lunak.

Permohonan dan registrasi tempat usaha yang dihasilkan oleh petugas sangat sulit dicari jika dibutuhkan. Dengan demikian perlu diterapkan sistem yang terkomputerisasi pada Kantor Kecamatan Kosambi Kabupaten Tangerang yang digunakan untuk membantu proses pendataan registrasi, penulisan laporan serta permohonan surat izin tempat usaha.

Dalam proses analisa sistem yang berjalan meggunakan metode analisa PIECES, sebagai berikut :

- Kinerja Sistem (Performance)adalah kinerja sistem pada Kantor Kecamatan Kabupaten Tangerang dalam proses pendataan permohonan berkas surat izin tempat usaha masih menggunakan buku agenda yang bisa saja rusak atau hilang, serta proses pembuatan laporan yang belum tertata dengan baik.

Informasi (Information) sangat dibutuhkan dalam pembuatan surat izin agar tidak terjadi kesalahan pada saat proses registrasi. Informasi yang tidak akurat bisa menimbulkan masalah yang cukup besar, oleh sebab itu perlu adanya sosialisasi tentang syarat dan prosedur dalam pembuat surat izin tempat usaha.

Ekonomi (Economy), yaitu dalam proses pembuatan surat izin mulai dari pengajuan registrasi hingga keluarnya sebuah surat izin tempat usaha membutuhkan biaya yang cukup besar.

Keamanan (Control) adalah pengontrolan dalam pembuatan surat izin masih belum sempurna dikarenakan masih banyak oknum yang memanfaatkan pembuatan surat izin untuk membuka usaha yang ilegal menjadi legal. Dalam penyimpanan arsip masih tidak tertata dengan baik sehingga terjadinya kehilangan berkas.

Efesiensi (Efeciency), banyaknya waktu yang terbuang untuk pendataan pembuatan surat izin tempat usaha disebabkan karena proses masih menggunakan buku agenda dan memasukannya kedalam Ms.word atau Ms.excel sehingga tidak efektif.

Layanan (Service), sistem pembuatan surat izin dalam Kecamatan Kosambi Kabupaten Tangerang masih memiliki kekurangan yaitu lamanya penerbitan surat izin, kurangnya persyaratan untuk membuat surat izin.

Setelah melakukan penelitian yang sedang berjalan saat ini, peneliti akan membahas tentang rancangan sistem yang akan dibuat. Adapun yang bertujuan untuk memperbaiki dan menyempurnakan sistem registrasi tempat usaha yang berjalan saat ini, yaitu merubah proses input data registrasi tempat usaha yang masih manual menjadi program yang memiliki sistem. 
Berdasarkan perubahan sistem registrasi tempat usaha sesuai kebutuhan sistem yang baru ditentukan, maka langkah selanjutnya yaitu perancangan sistem yang bertujuan untuk memperbaiki sistem yang berjalan saat ini.

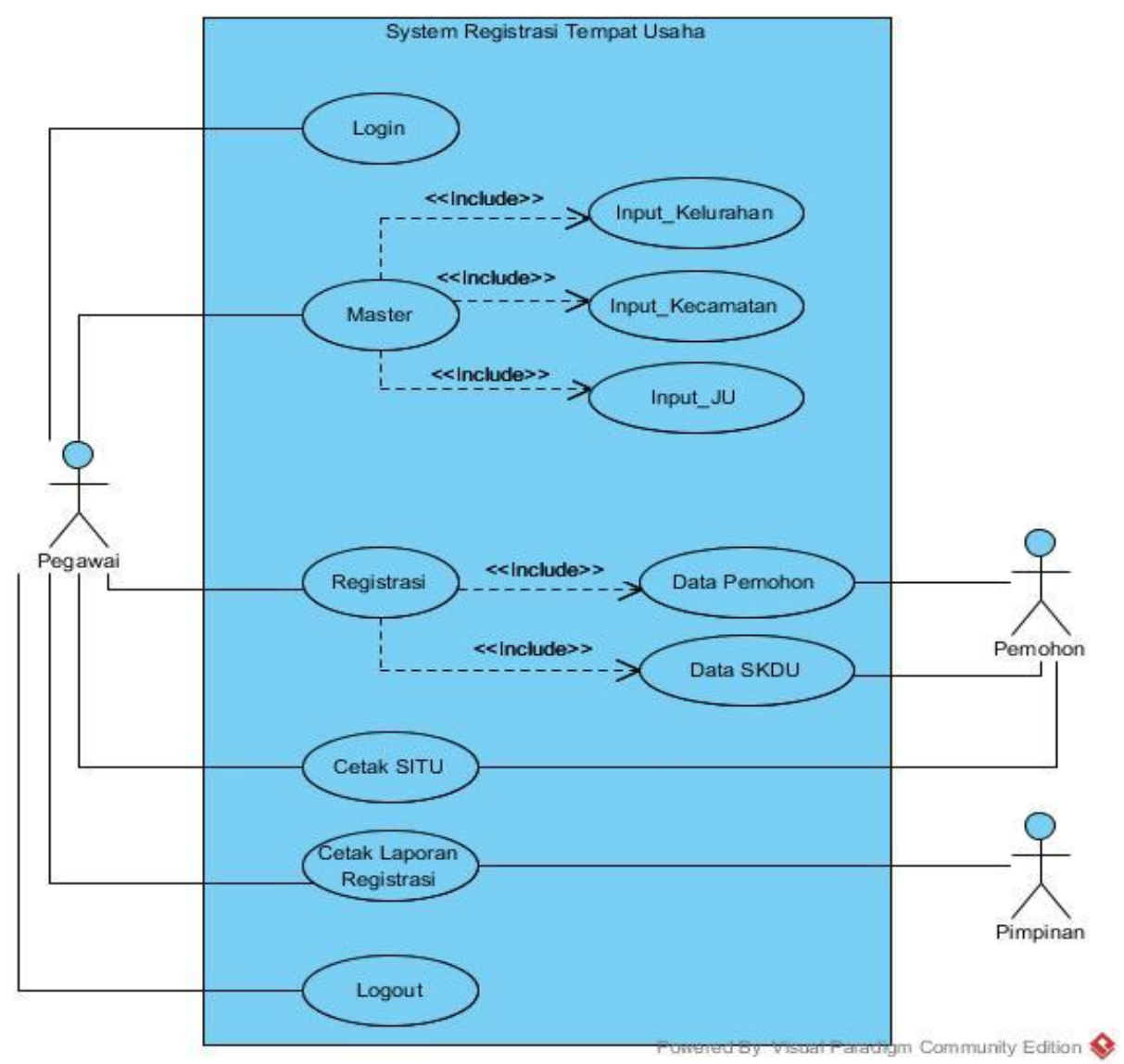

Gambar 1. Usecase Diagram

Rancangan layar (gambar 1) terdapat sebuah sistem yang mencakup kegiatan yang sedang berjalan.Tiga aktor yang melakukan kegiatan, yaitu Pegawai, Pemohon, dan Pimpinan. Pegawai melakukan login, menginput data master yang terdiri dari input data kelurahan, input data kecamatan, input jenis usaha. Pemohon masuk ke menu registrasi lalu masukan data pemohon, lampirkan data SKDU. Pegawai melakukan cetak SITU dan Pimpinan menerima Laporan Registrasi. Dan terdapat 12 use case yang dilakukan oleh 3 aktor, yaitu : Login, Master yang terdiri dari input data kelurahan, input data kecamatan, input jenis usaha, menu registrasi yang terdiri dari data pemohon, data SKDU. Cetak SITU, Cetak Laporan Registrasi, dan melakukan Logout. 


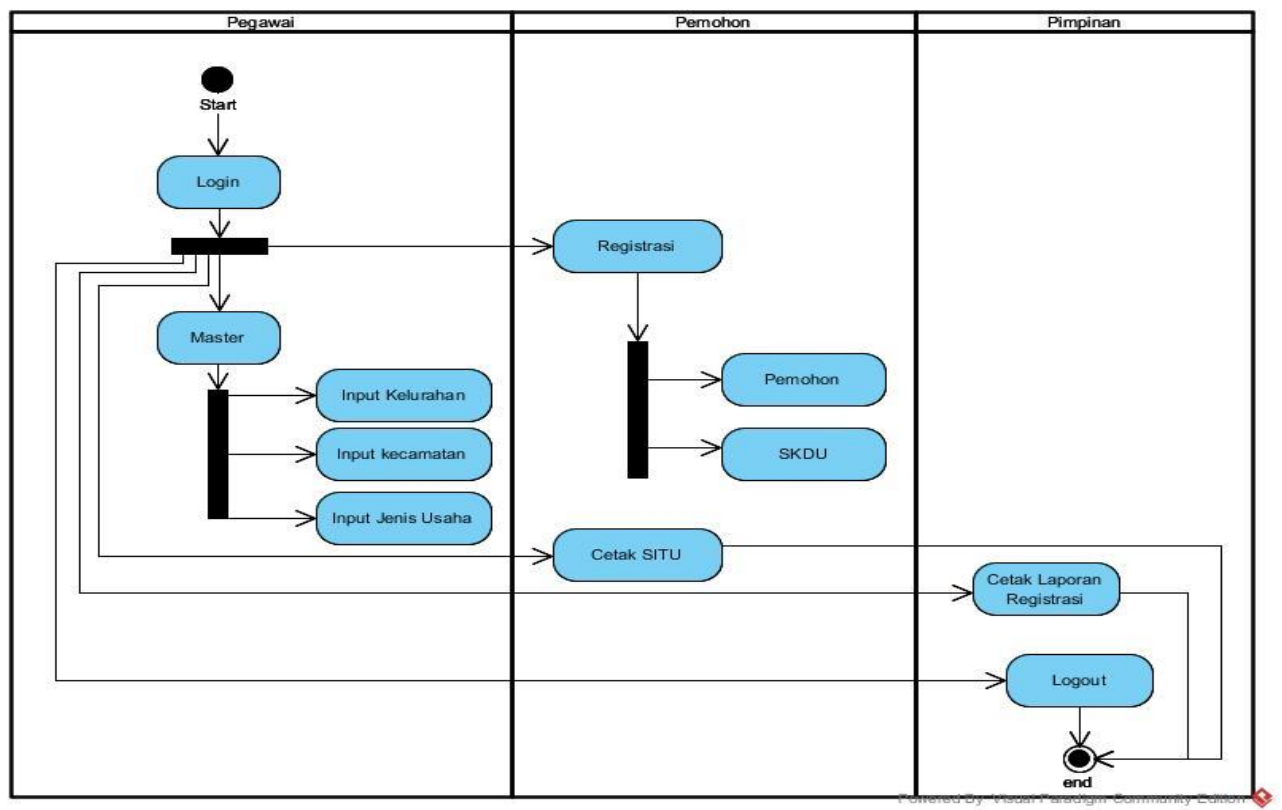

Gambar 2. Activity Diagram

Rancangan layar (gambar 2) terdapat 1 buat initial node sebagai start point dikolom pegawai.Memiliki 12 buah action sebagai proses yang berjalan, yang terdiri dari : Login, Master yang meliputi input data kelurahan, input data kecamatan, input jenis usaha, terdapat menu registarsi yang meliputi data pemohon, data SKDU. Cetak SKDU, Cetak Laporan registrasi, dan Logout. Terdapat 2 buah join node di masing-masing kolom aktor, untuk menghubungkan dari login ke master, login ke registrasi. Lalu ada 1 Fork node dibagian master digunakan pegawai untuk mengisi data master yaitu : Input data kelurahan, Input data kecamatan, Input data jenis usaha. Dan memiliki 1 buah final state sebagai end point dikolom pimpinan.

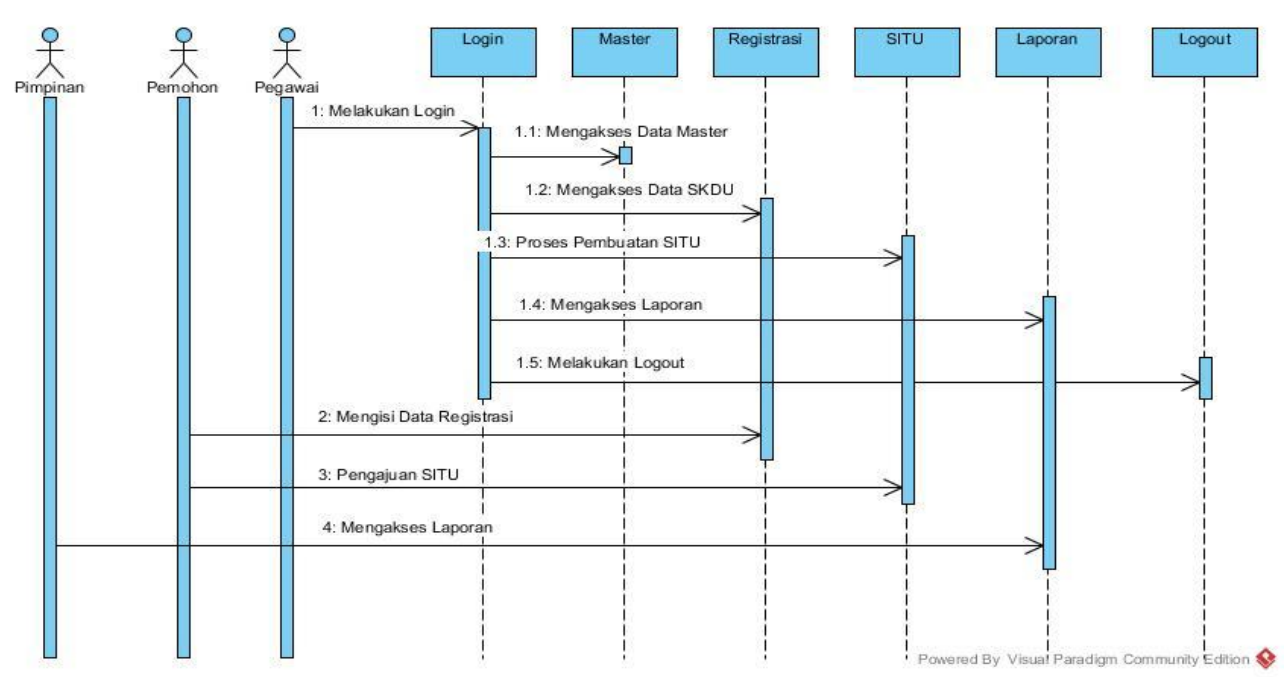

Gambar 3. Sequence Diagram

Rancangan layar (gambar3) terdapat 3 aktor yang memiliki kegiatan diantaranya Pegawai, Pemohon, Pimpinan. Memiliki 6 object yang saling berhubungan yaitu : Login, Master, Registrasi, Cetak SITU, Cetak Laporan Registrasi. Memuat 11 message 
dari komunikasi antar objek yang membuat sistem informasi tentang aktifitas yang terjadi, kegiatan yang biasa dilakukan oleh aktor tersebut, meliputi : Petugas melakukan Login, mengakses data master, mengakses data skdu, proses pembuatan SITU, mengakses laporan, dan logout. Pemohon mengisi data registrasi dan pengajuan pembuatan SITU. Camat mengakses laporan registrasi tersebut.

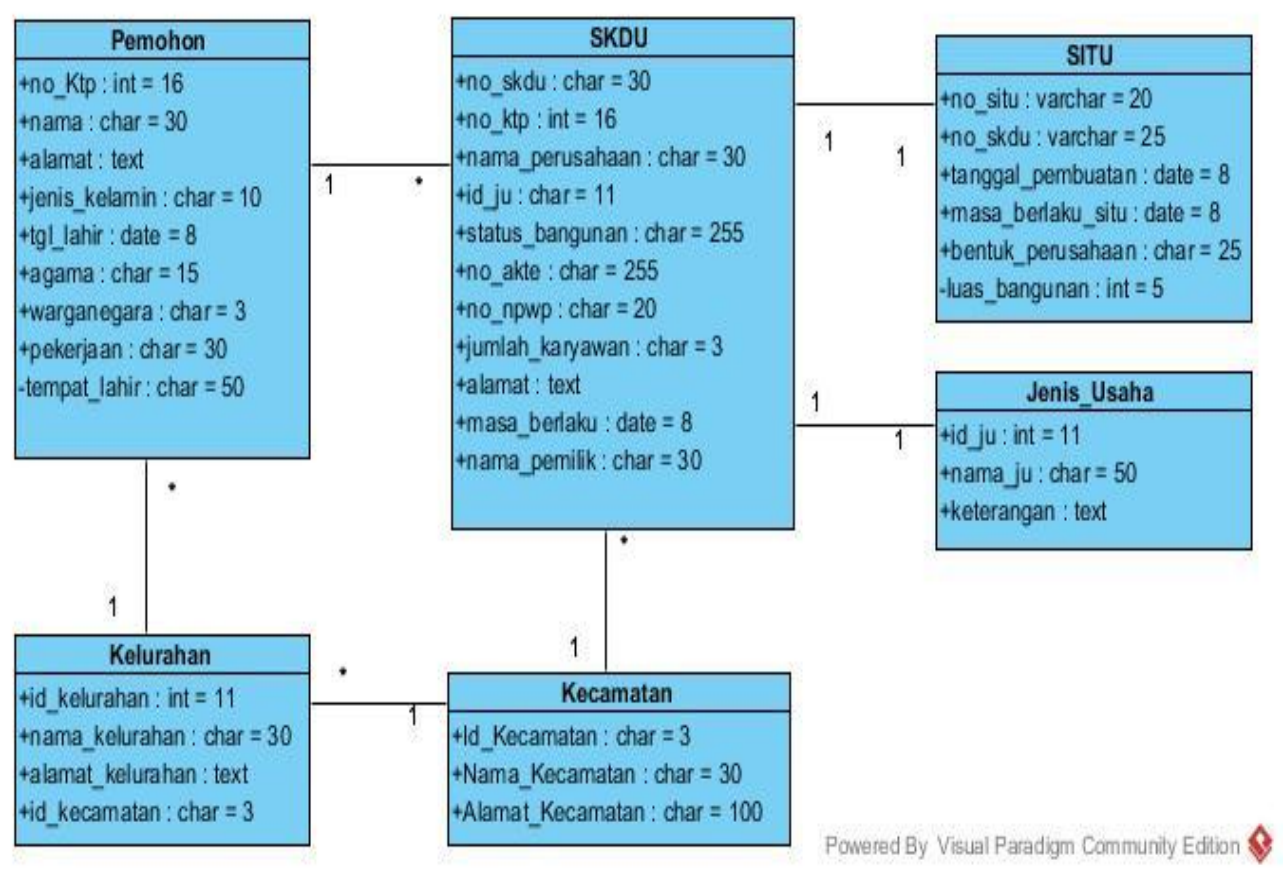

Gambar 4. Class Diagram

Rancangan layar (gambar 4) memiliki 6 class yang menggambarkan himpunan objek-objek yang berbagi atribut serta operasi yang sama, yang terdiri dari : Pemohon, Kelurahan, kecamatan, Jenis usaha, SKDU, SITU. Dan terdapat 6 association yang menunjukan hubungan antara objek satu dengan objek yang laiinya yang memiliki nilai.

\section{IMPLEMENTASI}

Rancangan Aplikasi dalam rancangan sistem informasi surat perizinan tempat usaha, penulis akan membuat rancangan aplikasi yang sesuai dengan kebutuhan pebagai dan juga penduduk, berikut adalah rancangan yang dibuat : 


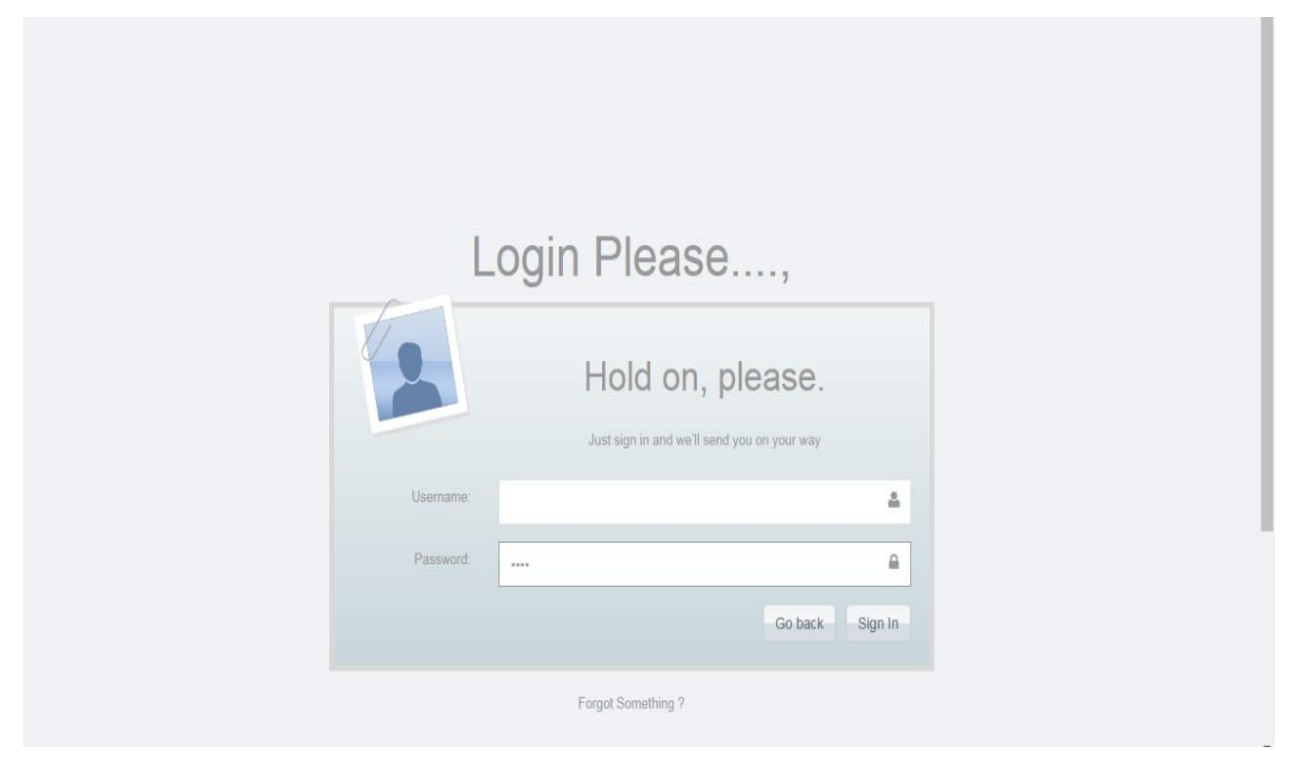

\section{Gambar 5. Tampilan Login}

Tampilan diatas (gambar 5) merupakan tampilan login yang digunakan oleh user jika ingin memasuki sistem registrasi dengan mengisi kolom username dan password.

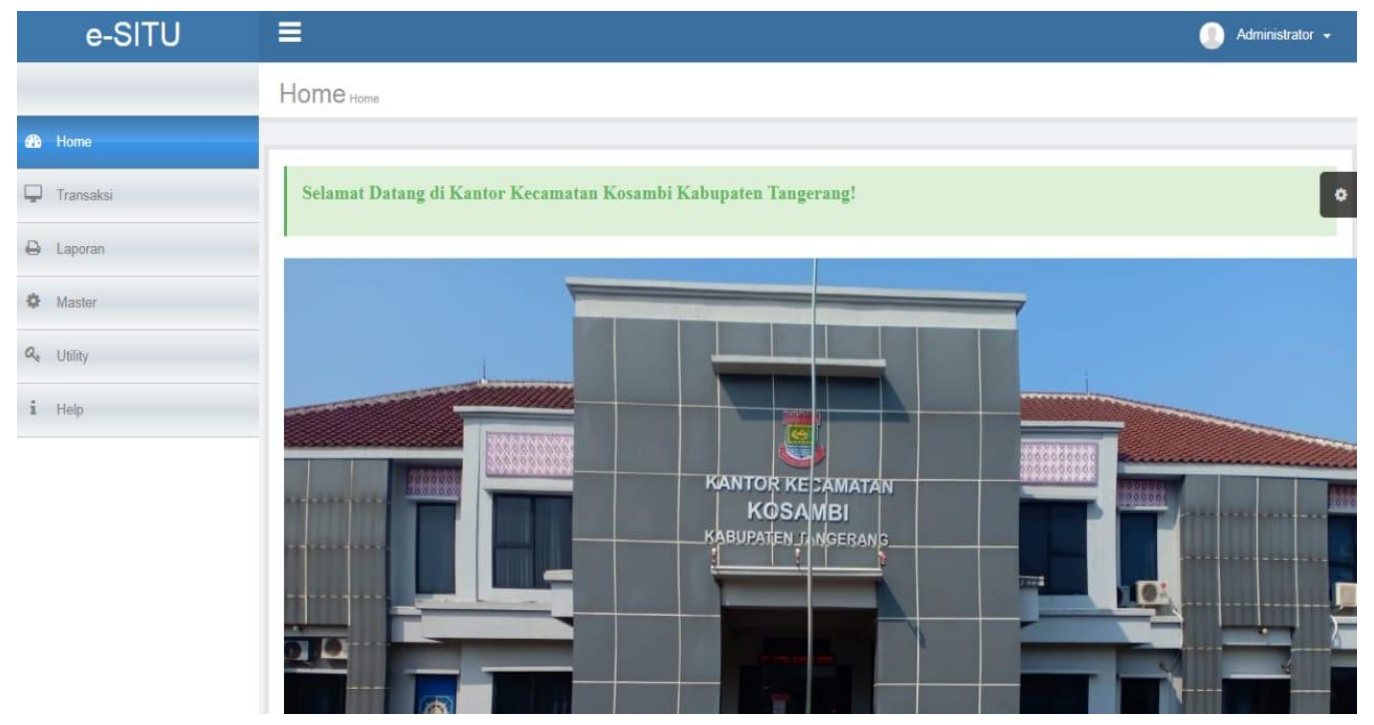

Gambar 6. Tampilan Home 
Tampilan diatas (gambar 6) merupakan tampilan awal atau home pada sistem registrasi yang digunakan oleh user ketika memasuki sistem registrasi.

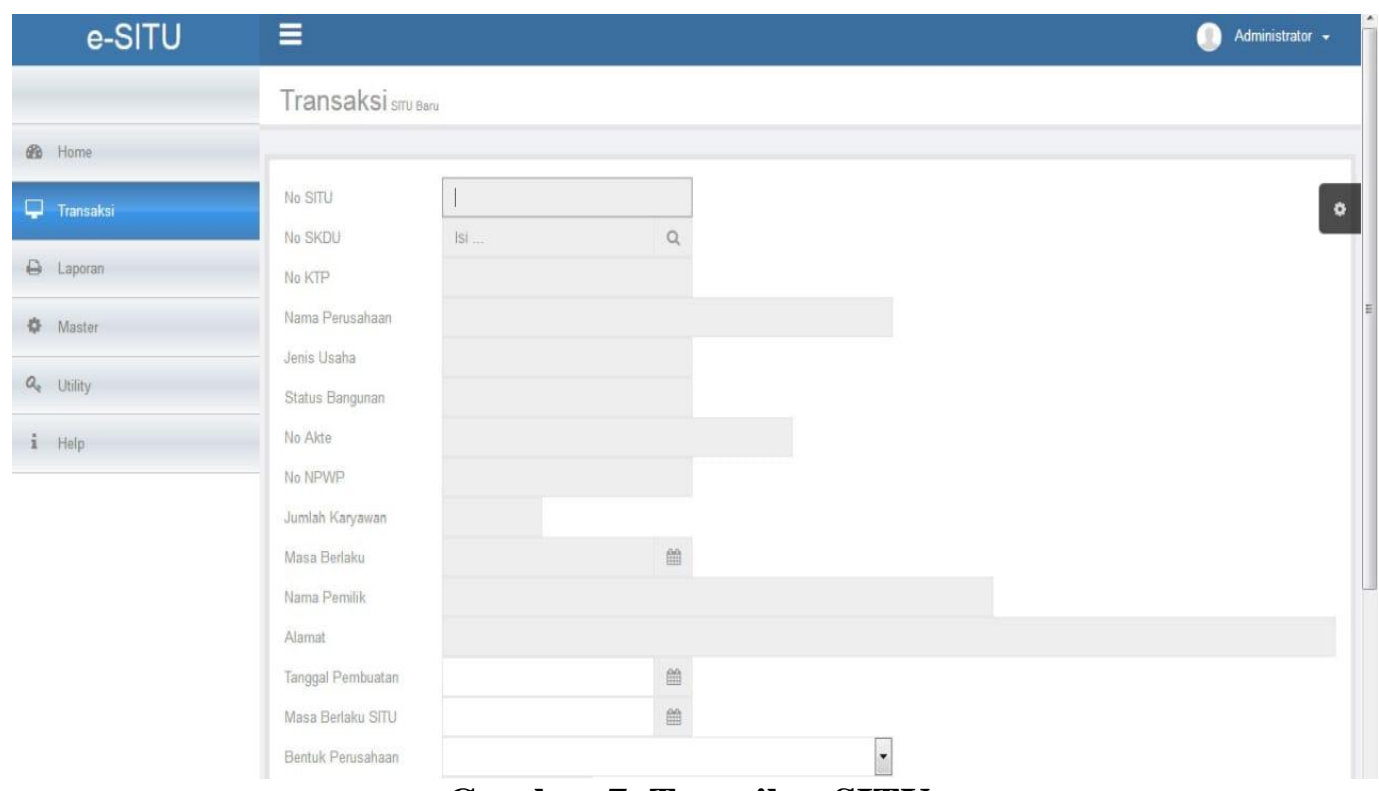

Gambar 7. Tampilan SITU

Tampilan diatas (gambar 7) menunjukan sebuah form registrasi SITU (Surat Izin Tempat Usaha) yang akan diisi oleh user untuk melengkapi data diri penduduk dan akan tersimpan didalam database sistem.

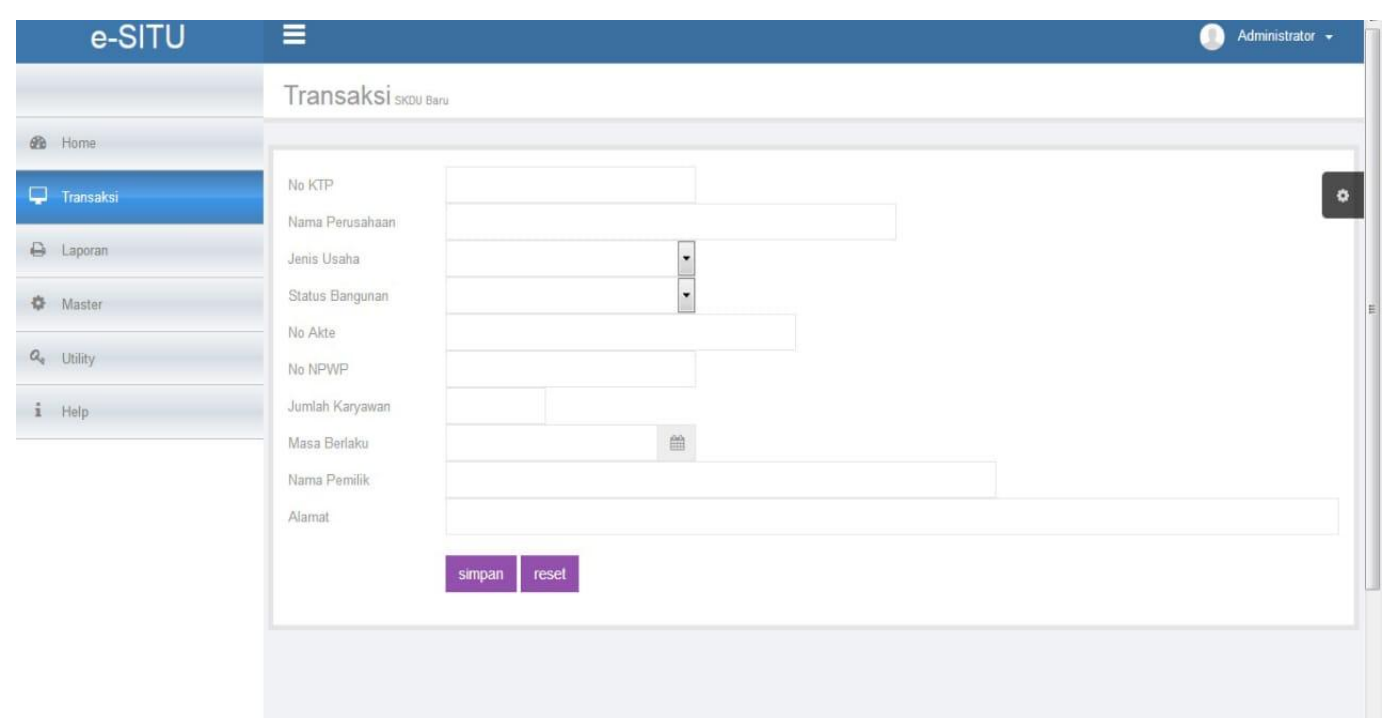

Gambar 8. Tampilan SKDU

Tampilan diatas (gambar 8) menunjukan sebuah form registrasi SKDU (Surat Keterangan Domisili Usaha) yang akan diisi oleh user untuk melengkapi data diri penduduk dan akan tersimpan didalam database sistem. 


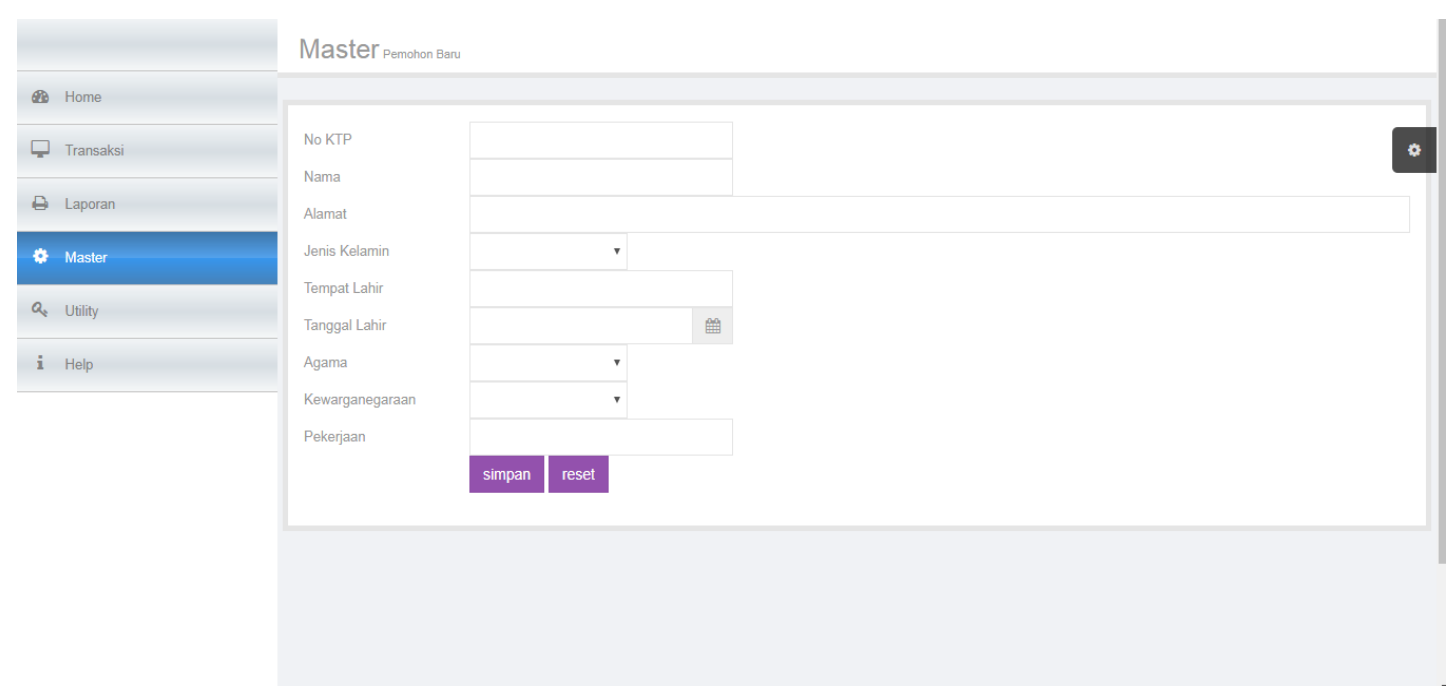

Gambar 9. Tampilan Data Pemohon

Tampilan diatas (gambar 9) menunjukan sebuah form datapemohon yang akan diisi oleh pemohon untuk melengkapi data diri penduduk dan akan tersimpan didalam database sistem.

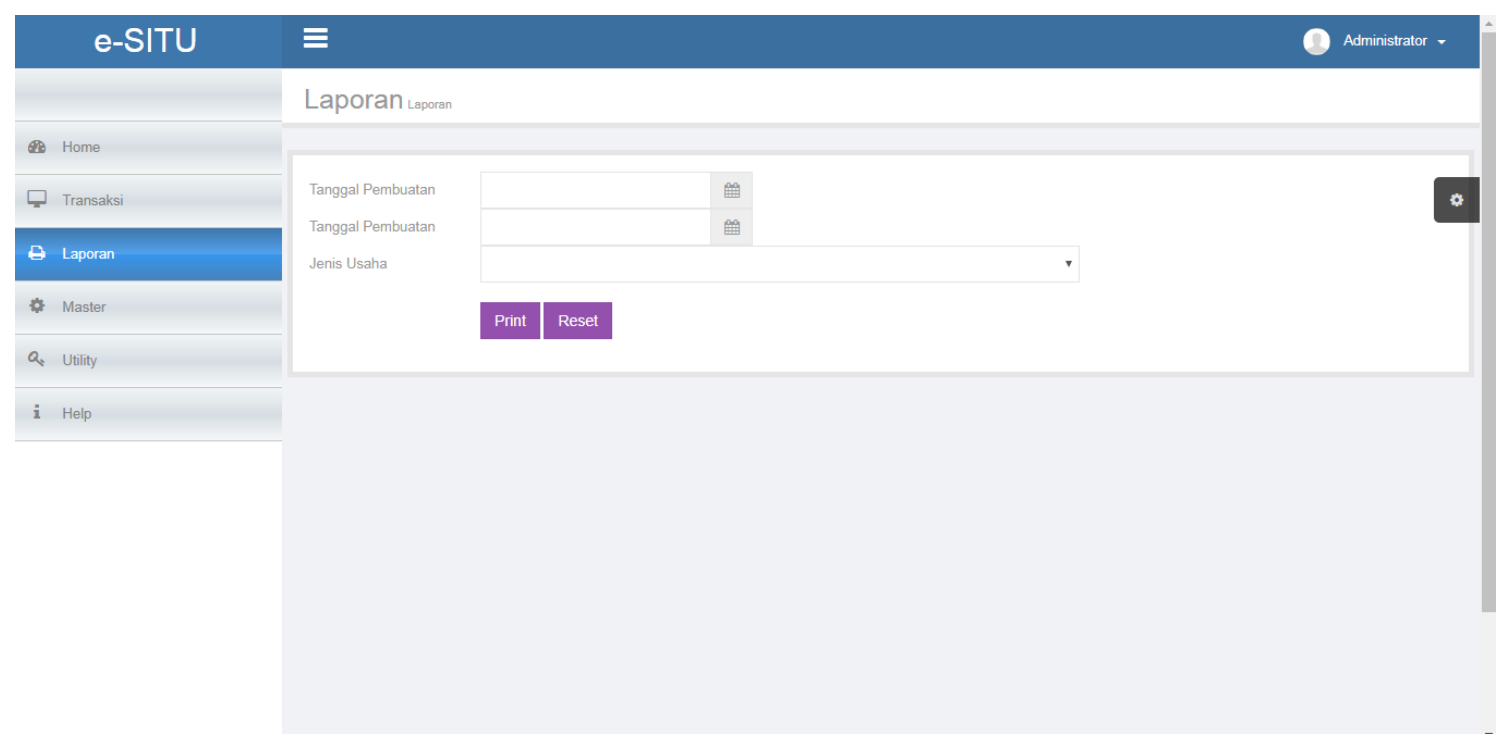

Gambar 10. Tampilan Laporan

Tampilan diatas (gambar 10) menunjukan sebuah form laporan untuk melihat data SITU (Surat Izin Tempat Usaha) yang sudah masuk berdasarkan tanggal pembuatan. 


\section{KESIMPULAN}

Dengan demikian dapat disimpulkan bahwa sistem informasi registrasi tempat usaha dapat mempermudah penduduk untuk melakukan proses registrasi dan mempermudah pegawai dalam menginput data permohonan registrasi tempat usaha. Dan dengan adanya sistem informasi registrasi tempat usaha berkas penduduk tersimpan dengan baik dan aman, dikarenakan penginputan data penduduk tersimpan secara otomatis. Sehingga dapat mendukung dalam proses meningkatkan kualitas pelayanan pada kantor kecamatan.

\section{DAFTAR PUSTAKA}

[1]. Akbar, Pacoyama Oktara. 2013. ANALISIS DAN PERANCANGAN SISTEM INFORMASI REGISTRASI ONLINE BERBASIS WEB.

[2]. Ando, Nazarius Hendro. 2013. Implementasi Kebijakan Pengurusan Surat Izin Tempat Usaha Di Kecamatan Nanga Taman Kabupaten Sekada. Jurnal ISSN Vol 2 No 2.

[3]. Bahram, Taufiq, dkk. 2015. Aplikasi Permohonan Surat Izin Tempat Usaha Berbasis Web Di Kantor Kelurahan. Jurnal ISSN 2089-3787.

[4]. Endang, Retnoningsih. 2015. Sistem Informasi Simpanan dan Pembiayaan Pada Baitul Maal Wat Tamwil (BMT) Al-Multazam Kabupaten Tegal. Jurnal IJSE.

[5]. Putra, Damba. 2017. KEBIJAKAN PEMERINTAH DALAM MEMBERIKAN IZIN USAHA INDUSTRI KECIL DI KOTA BANDAR LAMPUNG. Jurnal Ilmiah Hukum Administrasi Negara.

[6]. Riady, Y., Hartati, N., \& Daryusman, D. (2014). OPTIMASI DAN EVALUASI PENGGUNAAN REGISTRASI ONLINE DENGAN PENDEKATAN UTILITY SYSTEM (STUDI KASUS REGISTRASI ONLINE DI JAKARTA, TAIWAN DAN KOREA SELATAN 2013.1 dan 2013.2).

[7]. Yusmantoro, Sandi. dkk. 2014. Rancangan Bangun Aplikasi Pengamanan Keaslian Surat Izin Tempat Usaha Menggunakan Algoritma El Gamal dan Secure Hash Algorithm 256 Studi Kasus: Badan Pelayanan Perizinan Terpadu (BPPT) Kota Bengkulu. Jurnal Rekursif Vol 2 No 1. 